\title{
Isolation of Dental Caries Bacteria from Dental Plaque and Effect of Tooth Pastes on Acidogenic Bacteria
}

\author{
Dhruw Chandrabhan ${ }^{1}$, Rajmani Hemlata ${ }^{2}$, Bhatt Renu ${ }^{1}$, Verma Pradeep ${ }^{1 *}$ \\ ${ }^{1}$ Department of Biotechnology, Guru Ghasidas University, Bilaspur, India \\ ${ }^{2}$ Prayag Dental Clinic, Bilaspur, India \\ Email: chandrabhan.dhruw@yahoo.co.in, *vermaprad@yahoo.com
}

Received May 10, 2012; revised June 12, 2012; accepted June 25, 2012

\begin{abstract}
Destruction of calcified tissue was caused by acids which are by product of carbohydrate metabolism of acidogenic bacteria consequent to dental caries. The purpose of this study was to assess the existence of acidogens potentially causing the dental caries and comparatively evaluation of efficacy of different toothpastes. The dental plaques of fifty persons belong to three age groups (1 - 20, 21 - 40, 41 - 60 year and above) were examined to identify microorganisms by the culture method. Thirty nine bacteria were isolated by spread plate method on BSMY I minimal media. Thirteen out of thirty nine, acidogens colonized in the dental plaques. Seven potentially acidogens CD17, CD26, CD27, CD28, CD29, CD34 and CD35 were treated with five different toothpastes. Inhibition effect of Triclosan and Fluoride containing tooth pastes were found more efficient. The results of the present study revealed that bacteria that commonly cause dental caries colonized in dental plaques of children and alcoholic person. Therefore, dental plaques must be considered a specific reservoir of colonization and subsequent dental caries. To reduce the dental problem triclosan and fluoride containing product should be recommended.
\end{abstract}

Keywords: Dental Caries; Dental Plaque; Tooth Paste; Acidogens

\section{Introduction}

Dental caries is one of the most common chronic infectious diseases in the world $[1,2]$. Bacterial plaque accumulated on dental surfaces and composed of native oral flora is the primary etiologic agent of dental caries. Cariogenic bacteria interact by various recognized ways including co-aggregation [3], metabolic exchange, cellcell communication [4], and exchange of genetic material [5]. These mechanisms benefit bacterial survival and can make dental biofilms difficult therapeutic targets in dental diseases. Dental caries cause destruction of enamel, dentin or cementum of teeth due to bacterial activities. The burden of dental caries is still a major health problem in most industrialized countries as it affect $60 \%$ $90 \%$ of school-aged children and the vast majority of adult. This is largely due to the increasing consumption of sugar and inadequate exposure to fluorides [6].

Triclosan, a chlorophenol derivative, kill germs by interfering with the enzymes required for fatty acid synthesis. Similar to triclosan the fluorinated products were also found to possess marked antibacterial activities. These active compounds were reducing cariogenic bacteria to strengthen the teeth by reducing demineralization and

"Corresponding author. increasing remineralization of teeth [7].

Biofilms are surface-adherent population of microorganisms consisting of cells, water and extra cellular matrix material [8]. Streptococcus mutans, the principle cariogen for dental caries, co-exist with over 500 other species of bacteria as an interactive community known as the dental biofilm [9]. A quorum sensing signaling system is essential for genetic competence to function optimally in Biofilms [10]. Dental caries is a biofilm-dependent oral disease, and fermentable dietary carbohydrates are the key environmental factors involved in its initiation and development. Dental caries results from the interaction of specific bacteria with constituents of the diet within a biofilm termed "dental plaque" [11]. Sucrose is considered the most cariogenic dietary carbohydrate, because it is fermentable, and also serves as a substrate for the synthesis of extracellular (EPS) and intracellular (IPS) polysaccharides in dental plaque $[11,12]$. Enamel integrity is disrupted secondary to the formation of a dental biofilm and the caries process occurs along the interface between the dental biofilm and the enamel surface [13,14]. Cariogenicity of sucrose has been associated with its frequency of exposure and concentration $[15,16]$.

In order to understand and to know detail information on the micro flora of dental plaque in the individuals 
having different food habit and brush timing of different age groups, we have designed microbiological study, with special attention to the presence or absence of acidogenic bacteria in the dental plaque stored in reduced Transfer media. The purpose of this study was to assess the prevalence of dental plaque colonization by potential acidogens and to compare the efficacy of commercially available tooth pastes against those acidogens.

\section{Material and Methods}

\subsection{Sample Collection}

Fifty patients of five different zone of Bilaspur (C. G.) participated in this study. Ten samples from each zone were collected. However, food habit was similar for all, only differences were the brush timing and age. Three age groups were 1 - 20 (I), 21 - 40 (II), 41 - 60 and above (III) years. I group consume more sugar stuffs, II group consume all food stuffs in optimal amount but III consume alcoholic beverages and also have low immunity. Dental plaques from all patients were picked up through forceps and transferred into $2 \mathrm{ml}$ of reduced transport fluid medium $(0.4 \%$ agar, $0.15 \%$ thioglycollate/phosphate buffered saline) [17] in sterile tubes and stored at $4{ }^{\circ} \mathrm{C}$ and processed within one night of collection [18]. After explanation of the purpose of the study, all subjects or their families voluntarily provided informed consent in writing.

\subsection{Growth Media for Bacteria Isolation}

Basal salt medium with yeast extract (BSMY I) were used throughout this study. BSMY I [19], used for the isolation of bacteria from dental plaque samples contained: $1.0 \mathrm{~g}$ yeast extract, $0.3 \mathrm{~g}\left(\mathrm{NH}_{4}\right)_{2} \mathrm{SO}_{4}, 0.14 \mathrm{~g}$ $\mathrm{MgSO}_{4} \cdot 7 \mathrm{H}_{2} \mathrm{O}, 0.2 \mathrm{~g} \mathrm{CaCl}_{2} \cdot 2 \mathrm{H}_{2} \mathrm{O}, 0.1 \mathrm{~g} \mathrm{NaCl}, 0.05 \mathrm{~g}$ $\mathrm{KH}_{2} \mathrm{PO}_{4}, 0.05 \mathrm{~g} \mathrm{~K}_{2} \mathrm{HPO}_{4}, 0.6 \mathrm{mg} \mathrm{H}_{3} \mathrm{BO}_{3}, 0.17 \mathrm{mg}$ $\mathrm{CoCl}_{2} \cdot 6 \mathrm{H}_{2} \mathrm{O}, 0.09 \mathrm{mg} \mathrm{CuCl} \cdot 2 \mathrm{H}_{2} \mathrm{O}, 0.1 \mathrm{mg} \mathrm{MnCl}{ }_{2} \cdot 4 \mathrm{H}_{2} \mathrm{O}$, $0.22 \mathrm{mg} \mathrm{ZnCl} 2,10 \mathrm{~g}$ glucose in 1 liter of Tris- $\mathrm{HCl}$ buffer $(\mathrm{pH} 8.0)$. All the chemicals were used of analytical grade.

\subsection{Isolation of Bacteria from Dental Plaque}

Each sample in tubes was inoculated separately into 25 $\mathrm{ml}$ of BSMY I broth. Inoculated flasks were incubated at $35^{\circ} \mathrm{C} \pm 1^{\circ} \mathrm{C}$ for 48 hours. Freshly grown culture of $1 \mathrm{ml}$ from each dental plaque was serially diluted up to $10^{-5}$ with distilled water. $100 \mu \mathrm{l}$ serially diluted samples were spread over BSMY I agar plates. The inoculated plates were incubated at $37^{\circ} \mathrm{C}$ for 3 days under aerobic conditions. The isolated colonies were picked up and subsequent streaked on slant of BSMY I for pure culture preservation [20].

\subsection{Identification of Bacteria}

\subsubsection{Cultural Characteristics of Acidogens}

Cultural characteristics of isolated bacteria such as size, shape, pigmentation, elevation and margin of colony were recorded by culturing them on BSMY I medium and incubated for $24-48$ hours at $37^{\circ} \mathrm{C} \pm 1{ }^{\circ} \mathrm{C}$. The colonies were observed under transmitted and reflected light condition to understand their optical properties. For example colony characteristics were considered for CD26 was 2 - $4 \mathrm{~mm}$ diameter, irregular, white, convex/flat, raised, smooth, translucent colony under light [21].

\subsubsection{Morphological Characteristics}

The bacteria were gram stained and observed under light microscope $(40 \times)$. The shapes of bacterial cells were coccid, bacilli, single, paired, chain and dense clusters. CD26, CD28 are coccids and gram positive [20].

\subsubsection{Biochemical Properties}

Biochemical properties of the isolates were tested according to Bergey's Manual of Systematic Bacteriology [22]. The following properties were determined: Catalase test, acid production from carbohydrates glucose.

\subsubsection{Antibiotic Susceptible Test}

The susceptibility of the bacterial isolates to antimicrobial agents was determined using disk diffusion method [23] and interpreted according to Clinical and Laboratory Standards Institute (CLSI) [24] manuals. The following antimicrobial agents were obtained as standard reference disks for their known potency in laboratory use: Vancomycin (V) $10 \mu \mathrm{g}$, erythromycin (E) $15 \mu \mathrm{g}$, chloramphenicol (C) $10 \mu \mathrm{g}$ (Himedia). All of these tests were performed on plates of BSMY I. A $0.5 \mathrm{ml}$ of suspension of tested bacterial isolates was applied BSMY I plates. Antimicrobial disks were placed on the agar with sterile forceps. The agar plates were incubated inverted at $35^{\circ} \mathrm{C}$ for 24 hours. Results were recorded by measuring the inhibition zone.

\subsubsection{Toothpastes Assesses with Antibacterial Activity}

Five tooth pastes were used in the present study. Effects of Toothpastes were based on content they possess (Table 3). Tooth pastes stock was prepared in sterile distilled water $(0.5 \mathrm{~g} / \mathrm{ml})$. Acidogens were seeded to minimal media and made $3 \mathrm{~mm}$ well with the help of sterile cup borer. The samples were loaded $(25 \mu \mathrm{l})$ in a well and plates were kept in incubator at $35^{\circ} \mathrm{C} \pm 2^{\circ} \mathrm{C}$ for $24 \mathrm{hrs}$ [25].

\section{Result and Discussion}

\subsection{Prevalence of Bacteria}

From fifty samples of dental plaques thirty nine bacteria 
were isolated abbreviated as CD1 to CD39. Harshal [26] has reported as dental caries with a prevalence of as high as $60 \%-80 \%$ in children. Near $80 \%$ of the opportunistic bacteria isolated from plaque were found in saliva or tonsils, while $63 \%$ - $64 \%$ of the microbes present in saliva were present in dental plaques or tonsils [18]. This indicates organisms might be released from tooth surfaces into saliva and then colonizes on oral cavity surfaces such as the tonsils.

\subsection{Acidogens}

On the basis of acid production 13 bacteria were acidogenic. The potentially 7 acidogenic bacteria were subsequent treated with antibiotics and toothpastes, details are available in Table 1. Svensater et al. [27] had reported that nature of bacteria ability to produce acid (acidogenic) and tolerate acid environment (aciduric) are important that enable them to exhibit high dental caries. In India, a survey was carried out on school children showed caries prevalence of approximately 58\%. Surveys among the U.S. population showed an incidence of $45.3 \%$ in children and $93.8 \%$ in adults [28]. The enormous amounts of money and time are spent in treating dental caries. Hence, the prevention and control of dental caries is the main aim of public health, eventually the ultimate objective of public health is the elimination of the disease itself.

\subsection{Antibiotics Sensitivity Test}

The result of disk diffusion method revealed that most acidogenic bacteria were found resistant to antibiotics tested (Table 2). Out of seven acidogenic bacteria four were resistant to vancomycin, chloramphenicol, and erythromycin. Maripandi et al. [7] similarly reported that dental caries bacteria were resistant against vancomycin, chloramphenicol, penicillin, bacitracin and streptomycin.

\subsection{Antimicrobial Activity of Tooth Pastes}

The distilled water suspensions of the toothpaste were

Table 1. Prevalence of bacteria in dental plaques and selection of potential acidogens based on acid product produced from bacteria.

\begin{tabular}{llll}
\hline Samples & Isolated bacteria & $\begin{array}{l}\text { Acidogenic } \\
\text { bacteria }\end{array}$ & $\begin{array}{l}\text { Bacteria } \\
\text { tested }\end{array}$ \\
\hline A1-A10 & CD1-CD13 & CD8 & \\
A11-A20 & $\begin{array}{l}\text { CD14-CD17, CD39, } \\
\text { CD18-CD21 }\end{array}$ & $\begin{array}{l}\text { CD17, CD39, } \\
\text { CD20 }\end{array}$ & CD17 \\
& CD22-CD24, & CD24, CD26, & CD26, \\
A21-A30 & CD25-CD27, CD38 & CD27 & CD27 \\
& CD28, CD29, & CD28, CD29, & CD28, \\
A31-A40 & CD30-CD33 & CD30 & CD29 \\
& CD34, CD35, & CD34, CD35, & CD34, \\
A41-A50 & CD36, CD37 & CD36 & CD35 \\
\hline
\end{tabular}

Table 2. Antimicrobial activity was shown by antibiotics Erythromycin (E), chloramphenicol (C) and Vancomycin (V) the acidogens isolated from dental plaque.

\begin{tabular}{cccccc}
\hline \multirow{2}{*}{ S. No. } & \multirow{2}{*}{ Acidogens } & Acid test & \multicolumn{3}{c}{ Antibiotics } \\
\cline { 4 - 6 } & & & $\mathrm{E}$ & $\mathrm{C}$ & $\mathrm{V}$ \\
\hline 1. & $\mathrm{CD} 17$ & +++ & $\mathrm{R}$ & $\mathrm{R}$ & $\mathrm{R}$ \\
2. & $\mathrm{CD} 26$ & +++ & $\mathrm{R}$ & $\mathrm{R}$ & $\mathrm{R}$ \\
3. & $\mathrm{CD} 27$ & ++ & $\mathrm{S}$ & $\mathrm{S}$ & $\mathrm{S}$ \\
4. & $\mathrm{CD} 28$ & +++ & $\mathrm{S}$ & $\mathrm{S}$ & $\mathrm{S}$ \\
5. & $\mathrm{CD} 29$ & +++ & $\mathrm{R}$ & $\mathrm{R}$ & $\mathrm{R}$ \\
6. & $\mathrm{CD} 34$ & +++ & $\mathrm{R}$ & $\mathrm{R}$ & $\mathrm{R}$ \\
7. & $\mathrm{CD} 35$ & +++ & $\mathrm{S}$ & $\mathrm{S}$ & $\mathrm{S}$ \\
\hline
\end{tabular}

$+++=$ Highly acidic (Dark Yellow) $++=$ Acidic (Yellow); R = Resistant; S $=$ Sensitive.

found to have marked antimicrobial properties. The zones of inhibition against the acidogens results by the tooth pastes $\mathrm{T} 3$ was more effective followed by the T2 and T1, T4, T5 was least effective against the isolated acidogen (Figure 1). Furthermore, the efficacies of the tooth pastes regarding their chemical composition is not important especially in developing countries like India where low grade products can be found in local markets and consumers are forced unknowingly to choose the products [7]. Among the various tooth paste which have sodium fluoride and triclosan as the active ingredients marked as anticaries agents that prevent the formation of cavities in teeth. Other uses of anticaries agents include lessening mouth odors and polishing the teeth. Fluoride works by strengthening the calcium phosphate in teeth enamel. Tooth paste T1 possess fluoride, fluoride-releasing materials may perform better in caries inhibition in artificial caries model studies than non-fluoridated materials [29]. The main mechanism of fluoride cariostatic effect is described by Rolla et al. in 1993 [30] and noted that systemic fluoride was not effective due to very little fluoride incorporated into enamel through this approach. Topical fluoride application induces formation of fluorhydroxyapatite on the enamel and on the root surface and give a more acid resistance. Sorbitol also acts as a sweetener and makes more palatable. Silica is the ingredient that gives the toothpaste its abrasive quality. Toothpastes must be abrasive to remove plaque, stains and debris. It also does not scrape tooth enamel or damage gums [7]. In our study herbal paste (T4) which contained herbal extract of different medicinal plants (Piper nigram, P. langum, Zingiber officinale, Cinnamomum camphora, Menthos spicata) and did not contained triclosan and fluorides have less effective against acidogen. Triclosan and Fluoride containing Toothpastes were found to be highly effective against the acidogenic bacteria and similar effect shown by Maripandi et al. [7]. It showed that the toothpastes containing Triclosan as a major chemical ingredient posses significant antibacterial activities. Major ingredients of toothpastes were given in the Table 3 . 


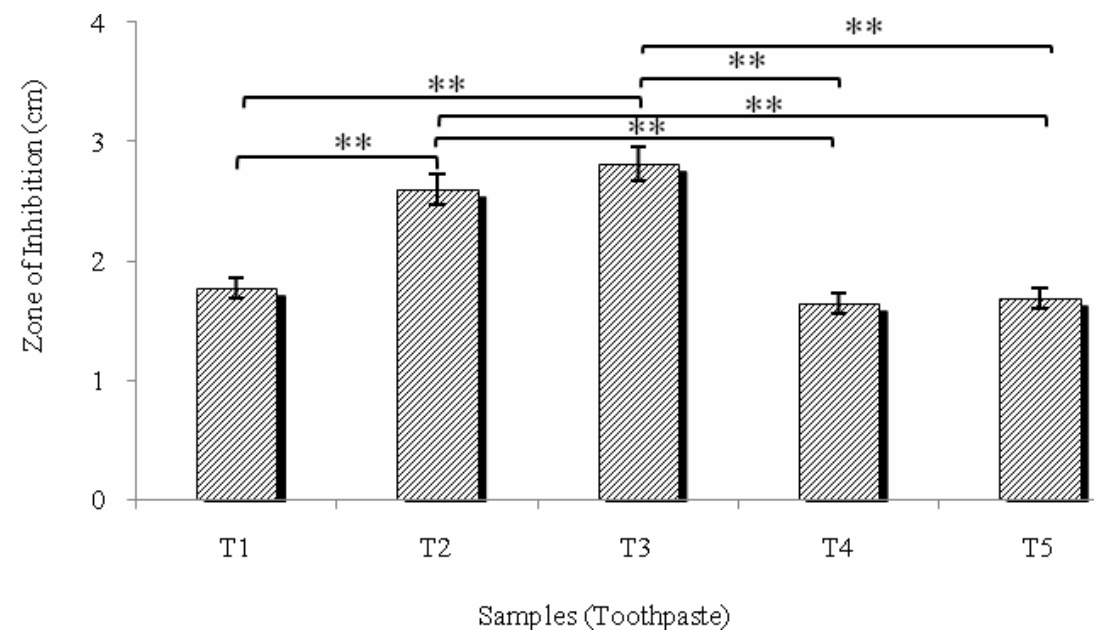

Figure 1. Efficacy of toothpastes (T1 - T5) on acidogenic bacteria isolated from dental plaque. Toothpaste solution was prepared with distilled water. Concentration of toothpastes was $0.5 \mathrm{mg} / \mathrm{ml}$ and distilled water used as control. Incubation was 24 hours at $35^{\circ} \mathrm{C} \pm 2^{\circ} \mathrm{C}$ on BSMY I media. Data are presented as mean \pm SDM. The T2 and T3 were significantly different from $\mathrm{T} 1, \mathrm{~T} 4$ and $\mathrm{T} 5$ as $* * P<0.01$.

Table 3. Tooth pastes were chosen according to their ingredients. Key ingredients are shown.

\begin{tabular}{|c|c|c|}
\hline S. No. & Toothpaste & Main ingredients \\
\hline 1. & $\mathrm{~T} 1$ & Fluoride \\
\hline 2. & $\mathrm{~T} 2$ & Carbonate, Triclosan \\
\hline 3. & $\mathrm{~T} 3$ & Carbonate, Triclosan and Benzyl alcohol \\
\hline 4. & $\mathrm{~T} 4$ & Carbonate, Herbal extract \\
\hline 5. & T5 & $\begin{array}{l}\text { Xanthan gum, Sorbitol, Glycerin and } \\
\text { Propylene glycol }\end{array}$ \\
\hline
\end{tabular}

T3 and T2 have good antibacterial effect against acidogenic bacteria than the Herbal tooth pastes. Ayurvedic contents of Herbal tooth pastes the Syzygium aromaticum (laung) helps to prevent toothache, Mentha requienii (pudina) helps to prevent bad breath and kills harmful germs. However Walsh et al. [31] similarly reported that the benefits of using fluoride tooth paste (T1) in preventing caries in children and adolescents.

\section{Conclusion}

In present study we observed that the acidogenic bacteria mainly colonized in dental plaque cause dental caries. Mainly the dental caries bacteria are resistant to antibiotics therefore regular use of tooth paste is better for prevention rather than use of antibiotic reported in present study. Triclosan and fluoride containing toothpastes were very effective against the Acidogenic bacteria. Aciduric bacteria were mainly colonized in alcoholic person and children (due maximum consumption of chocolate [sugar]). Toothpaste T3 and T2 content more amount of triclosan hence these tooth pastes formed large zone of inhibition than antibiotics and other toothpaste. Dental caries bacteria should be treated with triclosan containing product not with antibiotics having drugs to prevent the next generation superbug.

\section{REFERENCES}

[1] K. J. Anusavice, "Dental Caries: Risk Assessment and Treatment Solutions for an Elderly Population," Compendium of Continuing Education in Dentistry, Vol. 23, Suppl. 10, 2002, pp. 12-20.

[2] S. Y. Yoo, S. J. Park, D. k. Jeing, K. W. Kim, S. H. Lim, S. H. Lee, S. J. Choe, Y. H. Chang, I. S. Park and J. K. Kook, "Isolation and Characterization of the Mutans Streptococci from the Dental Plaques in Koreans," The Journal of Microbiology, Vol. 45, No. 3, 2007, pp. 246-255.

[3] P. E. Kolenbrander, R. J. Palmer Jr., A. H. Rickard, N. S. Jakubovics, N. I. Chalmers and P. I. Diaz, "Bacterial Interactions and Successions during Plaque Development," Periodontology, 2000, Vol. 42, No. 1, 2006, pp. 47-79. doi:10.1111/j.1600-0757.2006.00187.x

[4] Y. H. Li, N. Tang, M. B. Aspiras, P. C. Lau, J. H. Lee, R. P. Ellen and D. G. Cvitkovitch, "A Quorum-Sensing Signaling System Essential for Genetic Competence in Streptococcus mutans is Involved in Biofilm Formation," Journal of Bacteriology, Vol. 184, No. 10, 2002, pp. 2699 2708. doi:10.1128/JB.184.10.2699-2708.2002

[5] A. P. Roberts, G. Cheah, D. Ready, J. Pratten, M. Wilson and P. Mullany, "Transfer of TN916-Like Elements in Microcosm Dental Plaques," Antimicrobial Agents Chemotherapy, Vol. 45, No. 10, 2001, pp. 2943-2946. doi:10.1128/AAC.45.10.2943-2946.2001

[6] P. E. Petersen, D. Bourgeois, H. Ogawa, S. EstupinanDay and C. Ndiaye, "The Global Burden of Oral Diseases and Risks to Oral Health," Bulletin of the World Health Organization, Vol. 83, No. 9, 2005, pp. 661-669.

[7] A. Maripandi, A. T. Kumar and A. A. Al Salamah, "Prevalence of Dental Caries Bacterial Pathogens and Evaluation of Inhibitory Concentration Effect on Different Tooth 
Pastes against Streptococcus spp.," African Journal of Microbiology Research, Vol. 5, No. 14, 2011, pp. 17781783.

[8] I. W. Sutherland, "The Biofilm Matrix-An Immobilized but Dynamic Microbial Environment," Trends in Microbiology, Vol. 9, No. 5, 2001, pp. 222-227. doi:10.1016/S0966-842X(01)02012-1

[9] B. J. Paster, S. K. Boches, J. L. Galvin, R. E. Ericson, C. N. Lau and V. A. Levanos, "Bacterial Diversity in Human Subgingival Plaque," Journal of Bacteriology, Vol. 183, No. 12, 2001, pp. 3770-3783. doi:10.1128/JB.183.12.3770-3783.2001

[10] Y. H. Li, P. C. Y. Lau, J. H. Lee, R. P. Ellen and D. G. Cvitkovitch, "Natural Genetic Transformation of Streptococcus mutans Growing in Biofilms," Journal of Bacteriology, Vol. 183, No. 3, 2001, pp. 897-908. doi:10.1128/JB.183.3.897-908.2001

[11] W. H. Bowen, "Do We Need to Be Concerned about Dental Caries in the Coming Millennium?" Critical Reviews in Oral Biology \& Medicine, Vol. 13, No. 2, 2002, pp. 126-131. doi:10.1177/154411130201300203

[12] E. Newbrun, "Sucrose, the Arch Criminal of Dental Caries," Odontologisk Revy, Vol. 18, No. 4, 1967, pp. 373386.

[13] J. M. ten Cate, "Biofilms, a New Approach to the Microbiology of Dental Plaque," Odontology, Vol. 94, No. 1, 2006, pp. 1-9. doi:10.1007/s10266-006-0063-3

[14] A. T. Hara, M. Ando, C. Gonzalez-Cabezas, J. A. Cury, M. C. Serra and D. T. Zero, "Protective Effect of the Dental Pellicle against Erosive Challenges in Situ," Journal of Dental Research, Vol. 85, No. 7, 2006, pp. 612-616. doi:10.1177/154405910608500706

[15] A. F. Paes Leme, R. Dalcico, C. P. Tabchoury, A. A. Del Bel Cury, P. L. Rosalen and J. A. Cury, "In Situ Effect of Frequent Sucrose Exposure on Enamel Demineralization and on Plaque Composition after APF Application and F Dentifrice Use," Journal of Dental Research, Vol. 83, No. 1, 2004, pp. 71-75. doi:10.1177/154405910408300114

[16] C. P. Aires, C. P. Tabchoury, A. A. Del Bel Cury, H. Koo and J. A. Cury, "Effect of Sucrose Concentration on Dental Biofilm Formed In Situ and on Enamel Demineralization," Caries Research, Vol. 40, No. 1, 2006, pp. 28-32. doi:10.1159/000088902

[17] C. I. Hoover and E. Newbrun, "Survival of Bacteria from Human Dental Plaque under Various Transport Conditions," Journal of Clinical Microbiology, Vol. 6, No. 3, 1977, pp. 212-218.

[18] M. A. Salam, H. Senpuku, Y. Nomura, K. Matin, H. Miyazaki and N. Hanada, "Isolation of Opportunistic Pathogens in Dental Plaque, Saliva and Tonsil Sample from Elderly," Japanese Journal of Infectious Diseases, Vol. 54, No. 5, 2001, pp. 193-195.

[19] P. Aksornchu, P. Prasertsan and V. Sobhon, "Isolation of
Arsenic-Tolerant Bacteria from Arsenic-Contaminated Soil," Songklanakarin Journal of Science and Technology, Vol. 30, Suppl. 1, 2008, pp. 95-102.

[20] J. P. Harley and L. M. Prescott, "Bacterial Morphology and Staining," In: H. Prescott, Ed., Laboratory Exercises in Microbiology, 5th Edition, The McGraw-Hill Companies, New York, 2002, pp. 31-36.

[21] L. M. Prescott, J. P. Harley and D. A. Klein, "Isolation of pure cultures," In: H. Prescott, Ed., Microbiology, 5th Edition, The McGraw-Hill Companies, New York, 2002, pp. 106-110.

[22] R. N. Krieg, "Bergey's Manual of Systematic Bacteriology," Williams \& Wilkins, Baltimore, 1984.

[23] National Committee for Clinical Laboratory Standards, "Performance Standards for Disc Susceptibility Tests," 3rd Edition, Approved standard M2-A8, National Committee for Clinical Laboratory Standards, Wayne, 2003.

[24] Clinical and Laboratory Standards Institute (CLSI), "Performance Standards for Antimicrobial Susceptibility Testing," Approved standard M100-S20, National Committee for Clinical Laboratory Standards, Wayne, 2010.

[25] National Committee for Clinical Laboratory Standards (NCCLS), "Methods for Dilution Antimicrobial Susceptibility Tests for Bacteria that Grow Aerobically," 6th Edition, Approved standard M7-A6, National Committee for Clinical Laboratory Standards, Wayne, 2003.

[26] T. P. Harshal, "Recent Advances in Oral Health Care in India," Journal of Dental Research, Vol. 20, No. 1, 2009, pp. 129-130. doi:10.4103/0970-9290.49054

[27] G. Svensater, U.-B. Larsson, E. C. G.. Greif, D. G. Cvitkovitch and I. R. Hamilton, "Acid Tolerance Response and Survival by Oral Bacteria," Oral Microbiology and Immunology, Vol. 12, No. 5, 1997, pp. 266-273. doi:10.1111/j.1399-302X.1997.tb00390.x

[28] K. M. Shivakumar, S. K. Vidya and G. N. Chandu, "Dental Caries Vaccine," Indian Journal of Dental Research, Vol. 20, No. 1, 2009, pp. 99-106. doi:10.4103/0970-9290.49066

[29] F. M. Burke, N. J. Ray and R. J. McConnell Cork, "Fluoride-Containing Restorative Materials," International Dental Journal, Vol. 56, No. 1, 2006, pp. 33-43.

[30] G. Rolla, B. Ogaard and D. Cruz, "Topical Application of Fluorides on Teeth. A New Concept of Mechanism of Interaction," Journal of Clinical Periodontology, Vol. 20, No. 2, 1993, pp. 105-108. doi:10.1111/j.1600-051X.1993.tb00323.x

[31] T. Walsh, H. V. Worthington, A. M. Glenny, P. Appelbe, V. C. Marinho and X. Shi, "Fluoride Toothpastes of Different Concentrations for Preventing Dental Caries in Children and Adolescents," Evidence-Based Dentistry, Vol. 11, No. 1, 2010, pp. 6-7. doi:10.1038/sj.ebd.6400698 